\title{
Eggshell microbiology and quality of hatching eggs subjected to different sanitizing procedures
}

\author{
Winnie Luiza dos Santos Clímaco(1), Érica de Faria Melo(1), Diego Pereira Vaz ${ }^{(1)}$, \\ Mariana Masseo Saldanha(1), Maria Fernanda Vieira da Silva Pinto( ${ }^{(1)}$ \\ Letícia Carolina Cleto Fernandes ${ }^{(1)}$, Nelson Carneiro Baião(1), Letícia Goulart de Oliveira ${ }^{(2)}$, \\ Felipe Machado de Sant'Anna(2), Marcelo Resende de Souza(2) and Leonardo José Camargos Lara(2)
}

\begin{abstract}
(1)Universidade Federal de Minas Gerais, Escola de Veterinária, Departamento de Zootecnia, Campus Pampulha, Avenida Antônio Carlos, no 6.627, Caixa Postal 567, CEP 31270-901 Belo Horizonte, MG, Brazil. E-mail: winnieluiza@gmail.com, erica.melo@yahoo.com, diegopvaz@hotmail.com, marianamasseo@hotmail.com, mariafvsp@hotmail.com, cletoleticia@gmail.com, ncbaiao@vet.ufmg.br (2)Universidade Federal de Minas Gerais, Escola de Veterinária, Departamento de Tecnologia e Inspeção de Produtos de Origem Animal, Campus Pampulha, Avenida Antônio Carlos, no 6.627, CEP 31270-901 Belo Horizonte, MG, Brazil. E-mail: leticiagoliveira@yahoo.com, vetfelipem@gmail.com, marceloresende51@gmail.com, leonardo@vet.ufmg.br
\end{abstract}

Abstract - The objective of this work was to evaluate the effect of different disinfection procedures as alternatives to formaldehyde fumigation on eggshell microbial load and quality of eggs from a 42-weekold Cobb commercial breeder flock. A total of 10,080 clean eggs collected from the nests were randomly distributed in a randomized complete block design, among the following treatment groups: $13.33 \mathrm{~g} \mathrm{~m}^{-3}$ formaldehyde fumigation, 5-10 ppm ozone fumigation, $6.36 \mathrm{~mW} \mathrm{~cm} \mathrm{~cm}^{-2} \mathrm{UV}-\mathrm{C}$ light irradiation, spraying with $1.56 \%$ hydrogen peroxide, spraying with $0.13 \%$ peracetic acid, spraying with water (wet control), and no disinfection procedure (dry control). Per treatment, eight samples of four eggs each were collected before and after the disinfection procedure, in order to count the number of Enterobacteriaceae and total aerobic mesophilic bacteria on the eggshell. Only eggs subjected to the formaldehyde and UV treatments showed a significant reduction in total aerobic mesophilic bacterial count on the eggshell, when compared with those of the dry control group. Treatments did not affect eggshell thickness and resistance force. UV light exposure is effective in reducing microbial load on 42 -week-old breeder flock eggshells, without affecting their quality, and can be considered an alternative to formaldehyde disinfection.

Index terms: bacterial count, ozone, resistance force, sanitizers, thickness, UV light.

\section{Microbiologia e qualidade de casca de ovos incubáveis submetidos a diferentes procedimentos de desinfecção}

Resumo - O objetivo deste trabalho foi avaliar o efeito de diferentes procedimentos de desinfecção alternativos à fumigação com formaldeído sobre a redução da contagem microbiana e a qualidade de casca de ovos de matrizes Cobb de 42 semanas de idade. Um total de 10.080 ovos limpos coletados dos ninhos foi distribuído de maneira aleatória, em delineamento de blocos ao acaso, entre os seguintes tratamentos: fumigação com $13,33 \mathrm{~g} \mathrm{~m}^{-3}$ de paraformaldeído, fumigação com 5-10 ppm de ozônio, $6,36 \mathrm{~mW} \mathrm{~cm}^{-2}$ de irradiação de luz UV-C, pulverização com $1,56 \%$ de peróxido de hidrogênio, pulverização com $0,13 \%$ de ácido peracético, pulverização com água (controle úmido) e sem desinfecção (controle seco). Por tratamento, foram coletadas oito amostras de quatro ovos cada uma, momentos antes e após as desinfecções, para contagem de Enterobacteriaceae e bactérias mesófilas aeróbicas totais da casca. Somente os ovos submetidos aos tratamentos com formaldeído e UV apresentaram redução significativa nas contagens de bactérias mesófilas aeróbicas totais, quando comparados aos do grupo controle seco. Os tratamentos não influenciaram a espessura e a resistência da casca. A exposição de luz UV é eficaz em reduzir a contagem microbiana da casca de ovos de matrizes de 42 semanas de idade, sem afetar sua qualidade, e pode ser considerada alternativa ao uso de formaldeído para desinfecção.

Termos para indexação: contagem de bactérias, ozônio, resistência, desinfetantes, espessura, luz UV.

\section{Introduction}

The disinfection of fertile eggs is fundamental to prevent bacteria spreading from broiler breeder flocks to their offspring (Spickler et al., 2011). The embryo yolk sac and neonatal chicks are mainly contaminated in the laying environment by bacteria that can colonize the eggshell and penetrate into the egg through its pores (Cortés et al., 2004). Bacteria from the genera Escherichia, Enterobacter, Klebsiella, Staphylococcus, 
and Streptococcus have already been isolated and associated as agents involved in the infection of the yolk sac of broiler chicks (Cortés et al., 2004). Even eggs from clean nests have a certain amount of microorganisms on the eggshell that, under favorable growth conditions, may compromise the hatchability and health of neonatal chicks. On these eggshells, total aerobic mesophilic bacteria count can reach 3.75 to $7.07 \log _{10}$ colony-forming units (CFUs) per egg (Coufal et al., 2003; Zeweil et al., 2015). Therefore, reducing the eggshell microbial load through disinfection procedures would improve the quality of the egg to be incubated and reduce the incidence of bacterial infections in embryos and neonatal chicks (Fasenko et al., 2009).

Currently, formaldehyde fumigation is one of most used disinfectants for hatching eggs. However, this substance has been shown to have adverse effects on the embryo, as reported in a systematic review about formaldehyde fumigation (Cadirci, 2009). Due to its ability to diffuse into the eggs through their pores, this gas can alkylate cellular components, such as purine and pyrimidine bases present in the embryo DNA and RNA, causing embryonic death, mainly in the early stages of embryo development (Cadirci, 2009). In addition, formaldehyde use has been known to negatively affect the health of farm workers and hatchers, encouraging researchers to seek for alternative disinfection methods (Berrang et al., 2000). Therefore, for several years, disinfection of hatching eggs has been considered a problem for the poultry industry due to the absence of an economical, effective, and safe alternative to formaldehyde fumigation (Coufal et al., 2003).

In this context, researches are necessary to ensure effective methods for egg hygiene, considering the high probability of eggshell contamination after laying, as well as bird health care, poultry litter quality, and the correct egg collection procedures (Wells et al., 2010). The use of alternative eggshell disinfection procedures, such as spraying with peroxide-based disinfectants (Sander \& Wilson, 1999; Cox et al., 2007; Wells et al., 2011), ozone gas fumigation (Whistler \& Sheldon, 1989; Braun et al., 2011), and the use of UV-C light irradiation (Coufal et al., 2003; Wells et al., 2011), has been effective in reducing bacterial counts in eggshells. Moreover, since these methods do not release toxic residues after their use (Sheldon \& Brake,
1991; Braun et al., 2011), they can also be characterized as environmentally friendly.

Considering the effectiveness of some of these alternative disinfection methods in reducing eggshell microbial count, a more detailed knowledge about their action on eggshell quality is also necessary. The reason is that eggshell quality is directly related to the viability of the embryo (Roque \& Soares, 1994), which may suffer significant changes in its structure in response to the action of disinfectants, affecting embryonic development.

The objective of this work was to evaluate the effect of different disinfection procedures as alternatives to formaldehyde fumigation on eggshell microbial load and quality of eggs from a 42-week-old Cobb commercial breeder flock.

\section{Materials and Methods}

The experiment was carried out from February 25 to April 25, 2017, using eggs from a 42-week-old Cobb commercial broiler breeder flock, and was subdivided into two stages. The first one corresponded to the egg collection and disinfection procedures, in a commercial broiler breeder farm located in the municipality of Pitangui, in state of Minas Gerais, Brazil. The second, to the microbiological analysis of the eggs, at the microbiology laboratory of the veterinary school of Universidade Federal de Minas Gerais (UFMG). The experiment was approved by the ethics committee on animal use of UFMG, under protocol number 300/2016.

The disinfection procedures, as well as the evaluation of eggshell microbial count and quality, were performed using eggs from the third and fourth collection. The eggs were collected from the nests using disposable latex gloves, in order to avoid contamination between the hands of the collector and the eggs; eggs laid on litter or that were very dirty were discarded. Then, the eggs were packed in previously disinfected plastic flats. A total of 10,080 eggs were randomly selected and distributed among the disinfection treatments, totaling 1,440 eggs per treatment. The treatments consisted of five different disinfection procedures (ozone fumigation, fumigation with paraformaldehyde, irradiation with ultraviolet light type $\mathrm{C}$, hydrogen peroxide spraying, and peracetic acid spraying) and two controls (water spraying and no disinfection procedure), totaling seven. It should be noted that, immediately after the separation of eggs, a 
sample with 16 eggs was collected from each treatment for eggshell microbiological evaluation.

Each of the disinfection procedures and control treatments is described as follows. For ozone fumigation, the eggs were disinfected with ozone gas at the concentration of 5-10 ppm for $20 \mathrm{~min}$, according to the recommendations of the company that supplied the ozone generator (Alvap Engenharia Ltda., Lajeado, RS, Brazil). The gas was generated via compressed oxygen passing through the Alvap ozone generator (Alvap Engenharia Ltda., Lajeado, RS, Brazil), and the UV-100 UV ozone analyzer (Eco Sensors, Santa Fe, New Mexico, USA) was used for measurements inside the chamber. Each flat of collected eggs was placed in an uncovered plastic box, inside a $3-\mathrm{m}^{3}$ fumigation chamber, for disinfection. The air relative humidity was adjusted to $70 \%$ inside the chamber, as suggested by Braun et al. (2011), and was measured through a probe coupled to a thermohygrometer. Data of in-chamber ozone concentration recorded during disinfections are shown in Figure 1. After fumigation, the product was exhausted from the inside of the chamber during a total of $12 \mathrm{~min}$.

For fumigation with paraformaldehyde, a concentration of $13.33 \mathrm{~g} \mathrm{~m}^{-3}$ paraformaldehyde was used for egg disinfection, according to Cadirci (2009). Product firing, fumigation, and exhaustion totaled 20, 10 , and $10 \mathrm{~min}$, respectively. The flat of eggs used for this procedure was also placed in an uncovered plastic box, inside the fumigation chamber, which was the

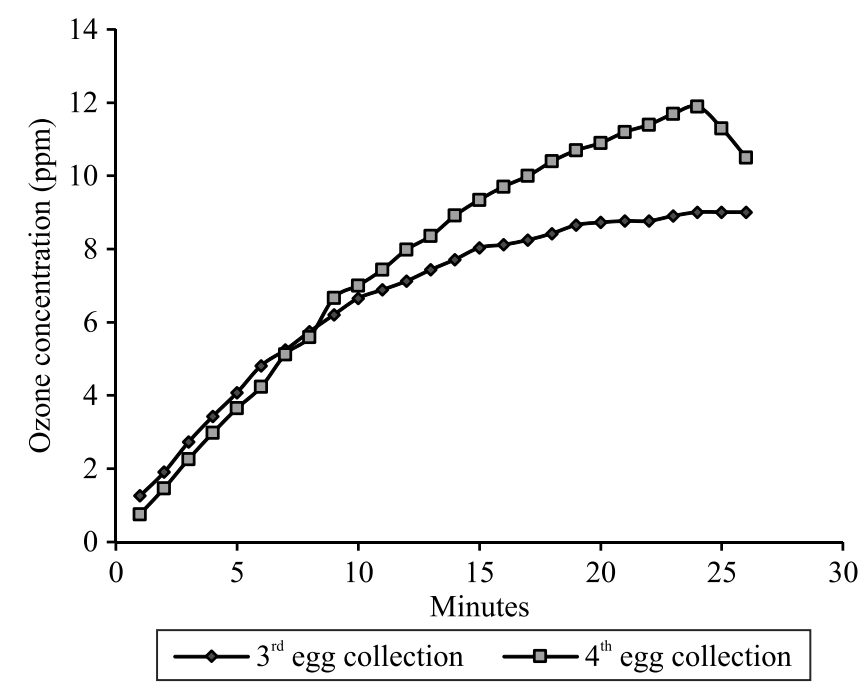

Figure 1. Ozone concentration (ppm) inside the ozone fumigation chamber during the disinfection of eggs from a 42-week-old Cobb broiler breeder flock. same one used to disinfect the eggs with ozone. For this reason, after each collection, the eggs were disinfected 1 hour later in relation to the other treatments; this hour included fumigation time plus the wait for total removal of the residues of the previously applied product. The air relative humidity inside the chamber was also adjusted to $70 \%$, as recommended by Cadirci (2009), and measured as in ozone fumigation.

For irradiation with type $\mathrm{C}$ ultraviolet light, using disposable latex gloves, the eggs were placed one by one on aluminum trays with a capacity of 95 eggs and then put inside a closed chamber, where $16 \mathrm{UV}-\mathrm{C}$ lamps -30 W, $90 \mathrm{~cm}$, and $254 \mathrm{~nm}$ (model G30T8 UVC, Halo Tech Co., Ltd., Shenzhen, China) - provided an average light intensity of $6.36 \mathrm{~mW} \mathrm{~cm}^{-2}$, as adapted from Gottselig et al. (2016). The egg trays, designed to prevent eggs from touching each other and, consequently, to allow a greater exposure to UV-C light, were positioned at the center of the chamber to allow the irradiation from eight lamps positioned above the entire extension of the tray and from eight lamps at the bottom of the chamber. In order to obtain significant reductions in eggshell microbial count, the disinfection time for each egg tray was $60 \mathrm{~s}$, the same used by Chavez et al. (2002). UV intensity was measured by the S401C probe coupled to the PM100D digital optical power meter, both from Thorlabs, Inc. (Newton, NJ, USA). The temperature inside the chamber was measured by a probe coupled to a digital thermometer, and ranged from 29.3 to $33.6^{\circ} \mathrm{C}$ throughout the disinfection period. A maximum of $35 \mathrm{~min}$ were spent to disinfect all eggs after each collection.

For hydrogen peroxide spraying, a solution of $1.56 \%$ hydrogen peroxide (Oxivir Five 16 Concentrate, JohnsonDiversey Brasil, São Paulo, SP, Brazil), with $650 \mathrm{ppm}$ active product, was used to disinfect the eggs, as recommended by the manufacturer. After each collection and separation of eggs, $500 \mathrm{~mL}$ disinfectant solution was sprayed onto 720 eggs at a time using a hand sprayer. The solution temperature was measured with the 5004 thermometer (Incoterm, Porto Alegre, $\mathrm{RS}$, Brazil) and ranged from 25 to $28^{\circ} \mathrm{C}$. To reach the whole surface of the eggs with the solution, the flats of eggs were placed on a horizontal surface and spraying was performed in two steps: $250 \mathrm{~mL}$ of the solution were distributed on one side of the eggs; and, after turning them, $250 \mathrm{~mL}$ were distributed on the other side. An average of $0.69 \mathrm{~mL}$ hydrogen peroxide was

Pesq. agropec. bras., Brasília, v.53, n.10, p.1177-1183, Oct. 2018 DOI: $10.1590 / \mathrm{S} 0100-204 X 2018001000011$ 
sprayed on each egg, and 8 to 10 min were spent on this procedure after each collection.

For peracetic acid spraying on eggshells, a solution of $0.13 \%$ peracetic acid (Divosan Forte, Diversey Brasil Indústria Química Ltda., São Paulo, SP, Brazil), with $200 \mathrm{ppm}$ active product, was used, according to the manufacturer's recommendations. The method and the amount of product used for spraying were similar to those for the hydrogen peroxide treatment. The solution temperature was measured as in the previous procedure and ranged from 23 to $26^{\circ} \mathrm{C}$. Total spraying time was from 7 to 12 min after each egg collection.

For spraying with water (wet control, without disinfection), at the end of each collection, the eggs were sprayed with only water to evaluate how egg wetting affected the studied variables. The procedure and the amount of water used for spraying were similar to those adopted when the other products were applied. Water temperature reached $27^{\circ} \mathrm{C}$ in all disinfections and was measured in the same way as in the other spraying procedures. The total time spent spraying eggs with water ranged from 10 to $13 \mathrm{~min}$ after each collection.

Finally, for the procedure without disinfection (dry control), the flats of eggs were kept in the same room where the other treatments were performed, but the eggs were not subjected to any disinfection procedure or sprayed with water after collection. Room temperature and humidity were recorded, ranging from 27.9 to $31.3^{\circ} \mathrm{C}$ and from 48 to $54 \%$, respectively.

Microbiological assessment was performed by a method adapted from Fasenko et al. (2009) for the evaluation of total aerobic mesophilic bacteria and Enterobacteriaceae. After each collection, just before and 1 hour after the disinfection, 16 eggs of each treatment were selected for eggshell microbial counts, totaling 32 eggs per treatment. The eggs, collected with disposable gloves, were placed in groups (pools) of four in autoclaved bags, which were properly identified according to each treatment and then refrigerated at $4^{\circ} \mathrm{C}$. The samples were transported to a laboratory, where the microbiological analyzes were performed 24 hours after refrigeration. Each bag was opened, and the eggs were moved to another autoclaved bag to which $250 \mathrm{~mL}$ phosphate-buffered saline (PBS) solution was added. The eggs were massaged for $5 \mathrm{~min}$ to remove bacterial cells from their surfaces. Then, a 1.0-mL sample of PBS was taken from each bag, and a series of three decimal dilutions in PBS were carried out for each sample. The plating of $1.0-\mathrm{mL}$ PBS from each dilution was performed on PCA agar (Oxoid Limited, Basingstoke, Hampshire, United Kingdom) and BD Difco MacConkey agar (Becton, Dickinson and Company, Franklin Lakes, NJ, USA), in order to obtain the count of total aerobic mesophilic microorganisms and Enterobacteriaceae, respectively. Plates were incubated at $37^{\circ} \mathrm{C}$ for 24 to 48 hours under aerobiosis conditions and, then, bacterial colonies were counted and recorded. Microbial counts were expressed as $\log _{10} \mathrm{CFU} 1.0 \mathrm{~mL}^{-1}$ pool of eggs.

Eggshell quality was evaluated based on eggshell resistance and thickness. To assess eggshell resistance, 24 eggs of each treatment were sampled. For this, the force (in grams) required to break the eggshell was determined by the TA.XT2 texture analyzer (Stable Micro Systems, Ltd., Surrey, United Kingdom). A 4-mm diameter stainless steel probe (P4 cylinder probe, Stable Micro Systems, Ltd., Surrey, United Kingdom) was used, at a distance of $6 \mathrm{~mm}$ and a speed of 3.0, 0.5, and $5.0 \mathrm{~mm} \mathrm{~s}^{-1}$ before, during, and after the test, respectively; the trigger force of the probe was $3.0 \mathrm{~g}$. The test followed the compression fracture method, according to Stefanello et al. (2014). Another 24 eggs were collected from each treatment for the measurement of eggshell thickness, following a method similar to the one used by Stefanello et al. (2014). Using a dissecting scissor, the eggshells were divided into three parts, corresponding to the apical (sharp end), equatorial, and basal (blunt end, with air chamber) regions. Eggshell thickness of the three regions was measured with the $\mathrm{MDH}-25 \mathrm{M}$ digital micrometer, with a resolution of $0.001 \mathrm{~mm}$ (Mitutoyo Asia Pacific Pte. Ltd., Singapore), and, then, the average thickness of the eggshell was calculated.

The other collected and disinfected eggs that were not used to assess the microbiology and quality of the eggshell were directed to a commercial hatchery for further evaluation of the hatching performance and quality of neonatal chicks, which will not be approached in the present study.

A randomized complete block design, with collections as blocks, totaling seven treatments, with eight replicates formed by a pool of four eggs, was used for the microbiological evaluation. A completely randomized design, consisting of seven treatments of 24 replicates each, with eggs as a replicate, was used 
to analyze eggshell quality. Data were subjected to the analysis of variance by the GLM procedure of the SAS software (SAS Institute, Inc., Cary, NC, USA), and means among treatments were compared by Tukey's test, at 5\% probability. Data that did not present normal distribution (bacterial counts) were transformed to the root of the variable and then subjected to the analysis of variance using the same procedure. For data did not present normality even after transformation, the test of Kruskal-Wallis, at 5\% probability, was used for the analysis and comparison of the means of the treatments.

\section{Results and Discussion}

Among the different disinfection procedures, only the eggs subjected to the formaldehyde and UV treatments showed a significant reduction in the counts of total aerobic mesophilic bacteria in relation to the control group (Table 1). In this case, formaldehydedisinfected eggs presented lower counts of total aerobic mesophilic bacteria than the UV-treated eggs. Furthermore, there were no differences for the counts of total aerobic bacteria and Enterobacteriaceae on eggshells before disinfection, and Enterobacteriaceae count was not affected by the treatments even after the application of the procedures.

Eggshell contamination by total aerobic mesophilic bacteria, before any disinfection procedure, varied between 3.17 and $3.57 \log 10 \mathrm{CFU} \mathrm{mL}^{-1}$, corroborating the results observed by Coufal et al. (2003) for eggs collected from nests. However, values between 4.0 and $7.0 \log 10 \mathrm{CFU}$ per clean egg were also described by some authors (Wells et al., 2011; Zeweil et al., 2015), which shows how the values for the initial contamination of the eggshell vary greatly between studies. Regardless of the microbial challenge to which the eggs were subjected to before disinfection, the treatments with formaldehyde and UV were effective in reducing the contamination of the eggshell by total aerobic mesophilic bacteria in 2.0 and $1.0 \log 10 \mathrm{CFU}$ $\mathrm{mL}^{-1}$, respectively. Coufal et al. (2003) also found a significant reduction in the total aerobic mesophilic microorganism population in eggshells exposed to UV light irradiation during $60 \mathrm{~s}$ at 7.5 and $4-14 \mathrm{~mW} \mathrm{~cm}{ }^{-2}$. In the present study, compared with formaldehyde fumigation, it was not possible to achieve the same microbial reduction pattern with UV light. As suggested by Coufal et al. (2003), this result may be due to the difficulty of UV light reaching the entire surface of the egg, making it impossible to expose the bacteria to irradiation and, therefore, to cause a greater reduction in the eggshell microbial count. Other possible explanations may be related to the adopted light intensity and exposure times, which were not enough to match or exceed the reduction values due to formaldehyde fumigation.

Although low, the number of total aerobic bacterial counts for the groups of eggs disinfected with ozone, hydrogen peroxide, and peracetic acid $(2.95,2.91$, and $3.05 \log _{10} \mathrm{CFU} \mathrm{mL} \mathrm{m}^{-1}$, respectively) was statically similar to that of the control group, with $3.14 \log 10 \mathrm{CFU} \mathrm{mL} \mathrm{m}^{-1}$

Table 1. Counts of total aerobic mesophilic bacteria (TAMB) and Enterobacteriaceae before and after the disinfection of eggshells of eggs from a 42-week-old Cobb broiler breeder flock, using the formaldehyde, ozone, ultraviolet light, hydrogen peroxide, peracetic acid, wet control (water spraying), and dry control (no disinfection) treatments, followed by the respective standard deviations (SD).

\begin{tabular}{|c|c|c|c|c|}
\hline \multirow[t]{2}{*}{ Treatment } & \multicolumn{2}{|c|}{ TAMB $\left(\log _{10} \mathrm{CFU} \mathrm{mL} \mathrm{mL}^{-1}\right.$ pool of four eggs $\left.\pm \mathrm{SD}\right)$} & \multicolumn{2}{|c|}{ Enterobacteriaceae $\left(\log _{10} \mathrm{CFU} \mathrm{mL} \mathrm{m}^{-1}\right.$ pool of four eggs $\left.\pm \mathrm{SD}\right)$} \\
\hline & Before treatment $t^{(1)}$ & After treatment ${ }^{(2)}$ & Before treatment ${ }^{(1)}$ & After treatment ${ }^{(2)}$ \\
\hline Formaldehyde & $3.42 \pm 0.29 \mathrm{a}$ & $1.10 \pm 0.16 \mathrm{a}$ & $1.27 \pm 0.64 \mathrm{a}$ & $1.04 \pm 0.00 \mathrm{a}$ \\
\hline Ozone & $3.31 \pm 0.42 \mathrm{a}$ & $2.95 \pm 0.41 \mathrm{c}$ & $1.08 \pm 0.10 \mathrm{a}$ & $1.37 \pm 0.69 \mathrm{a}$ \\
\hline Ultraviolet light & $3.57 \pm 0.24 \mathrm{a}$ & $2.20 \pm 0.56 b$ & $1.11 \pm 0.13 \mathrm{a}$ & $1.04 \pm 0.00 \mathrm{a}$ \\
\hline Hydrogen peroxide & $3.28 \pm 0.39 \mathrm{a}$ & $3.05 \pm 0.16 \mathrm{c}$ & $1.24 \pm 0.38 \mathrm{a}$ & $1.04 \pm 0.00 \mathrm{a}$ \\
\hline Peracetic acid & $3.24 \pm 0.35 \mathrm{a}$ & $2.91 \pm 0.67 \mathrm{c}$ & $1.37 \pm 0.84 \mathrm{a}$ & $1.39 \pm 0.72 \mathrm{a}$ \\
\hline Wet control & $3.17 \pm 0.22 \mathrm{a}$ & $3.16 \pm 0.44 \mathrm{c}$ & $1.13 \pm 0.26 \mathrm{a}$ & $1.43 \pm 0.61 \mathrm{a}$ \\
\hline Dry control & $3.36 \pm 0.36 \mathrm{a}$ & $3.14 \pm 0.42 \mathrm{c}$ & $1.16 \pm 0.22 \mathrm{a}$ & $1.08 \pm 0.10 \mathrm{a}$ \\
\hline Standard error of the mean & 0.0466 & 0.0572 & 0.0596 & 0.0591 \\
\hline P-value & 0.3605 & $<0.0001$ & 0.9674 & 0.1723 \\
\hline
\end{tabular}

(1)Means followed by equal letters, in the columns, do not differ by Tukey's test, at $5 \%$ probability. ${ }^{(2)}$ Means followed by different letters, in the columns, differ by the Kruskall-Wallis test, at 5\% probability. CFU, colony-forming unit. 
(Table 1). This result indicates that the use of such disinfectants was not effective in reducing microbial count on eggshells. Specifically in relation to ozone disinfection, Whistler \& Sheldon (1989) observed a significant reduction of $2.5 \log _{10}$ in the count of these microorganisms on eggshells, which was not observed in the present study. This difference is probably related to the time spent in disinfecting the eggshell, since the authors adopted a disinfection period considered long, of about 2 hours, which can be impractical at an industrial scale.

Regarding the eggs disinfected with peroxide-based products, i.e., hydrogen peroxide and peracetic acid, the absence of a significant response in microbial count could be related to the concentration of the used product. Even when the manufacturer's recommendations were followed, it was not possible to observe microbial reduction in the eggshells. Therefore, increasing the concentration of these products may lead to a significant reduction in total aerobic mesophilic bacteria, as reported by other authors (Sheldon \& Brake, 1991; Cox et al., 2007; Wells et al., 2011).

As to Enterobacteriaceae count on the eggshell, in all treatment groups, the obtained results differed from those of Fasenko et al. (2009), who did not observe the presence of this family of bacteria on eggshells, whether disinfected or not. In the present study, very low Enterobacteriaceae counts were verified in all groups, even before disinfection, in alignment with Musgrove et al. (2014). Therefore, the count means, both in the control groups and in the disinfected eggs, were below the required for a precise microorganism count per plate (Corry et al., 2007), making the results inaccurate. The rapid penetration of this group of bacteria through the egg pores after laying and the absence of colonization of Enterobacteriaceae on the eggshell are hypotheses that can justify the low count of these microorganisms.

The thickness and resistance of the eggshell were not affected by the applied treatments (Table 2). The results obtained for thickness $(0.34$ to $0.36 \mathrm{~mm})$ and resistance (4.12 to $4.51 \mathrm{~kg} \mathrm{~mm}^{-2}$ ), in all groups, are in agreement with those found by Gualhanone et al. (2012) and Yan et al. (2014), respectively. As thickness is one of the factors directly related to eggshell resistance (Robert, 2004), the absence of a statistical difference among groups regarding the later was also expected. A reduction in eggshell thickness due to the action of disinfectants could compromise the resistance of
Table 2. Means for thickness and resistance of eggshells of eggs from a 42-week-old Cobb broiler breeder flock due to the application of the formaldehyde, ozone, ultraviolet light, hydrogen peroxide, peracetic acid, wet control (water spraying), and dry control (no disinfection) treatments, followed by the respective standard deviations (SD) ${ }^{(1)}$.

\begin{tabular}{lcc}
\hline Treatment & $\begin{array}{c}\text { Thickness } \\
(\mathrm{mm} \pm \mathrm{SD})\end{array}$ & $\begin{array}{c}\text { Resistance } \\
\left(\mathrm{kg} \mathrm{mm}^{-2} \pm \mathrm{SD}\right)\end{array}$ \\
\hline Formaldehyde & $0.35 \pm 0.020 \mathrm{a}$ & $4.40 \pm 0.651 \mathrm{a}$ \\
Ozone & $0.36 \pm 0.018 \mathrm{a}$ & $4.51 \pm 0.623 \mathrm{a}$ \\
Ultraviolet light & $0.35 \pm 0.018 \mathrm{a}$ & $4.48 \pm 0.680 \mathrm{a}$ \\
Hydrogen peroxide & $0.34 \pm 0.024 \mathrm{a}$ & $4.51 \pm 0.621 \mathrm{a}$ \\
Peracetic acid & $0.35 \pm 0.018 \mathrm{a}$ & $4.12 \pm 0.612 \mathrm{a}$ \\
Wet control & $0.35 \pm 0.020 \mathrm{a}$ & $4.41 \pm 0.612 \mathrm{a}$ \\
Dry control & $0.36 \pm 0.024 \mathrm{a}$ & $4.47 \pm 0.502 \mathrm{a}$ \\
\hline SEM & 0.0016 & 0.0476 \\
P-value & 0.1066 & 0.3294 \\
\hline
\end{tabular}

(1)Means followed by equal letters, in the columns, do not differ by Tukey's test, at $5 \%$ probability. SEM, standard error of the mean.

this structure and lead to a higher incidence of breaks and/or bacterial penetration during incubation, which could affect embryonic viability. However, as shown in Table 2, none of the procedures negatively affected these variables. Despite this, an analysis of eggshell ultrastructure is strongly indicated for a more accurate evaluation of the effect of disinfection procedures on the different layers of the eggshell, especially the cuticle.

\section{Conclusions}

1. Only UV light radiation and formaldehyde fumigation are effective in reducing the aerobic mesophilic bacterial count on eggshells of eggs from a 42-week-old Cobb broiler breeder flock, compared with the control group.

2. UV light is recommended as an effective alternative procedure for the large-scale disinfection of hatching eggs.

3. Eggshell ultrastructure evaluations are necessary to determine if UV light actually does or not affect the eggshell cuticle.

\section{Acknowledgments}

To Cobb Vantress, Inc., for financial support; to Rafael Carreon from Cobb Vantress, Inc., for technical support; to Pif Paf Alimentos, for support; to the professionals Leonardo Eugênio de Araújo Ruiz, 
Antônio Queiroz Coelho, and Clever José Santos from Pif Paf Alimentos, for assistance during the field assay; and to Coordenação de Aperfeiçoamento de Pessoal de Nível Superior (Capes), for the scholarship granted.

\section{References}

BERRANG, M.E.; COX, N.A.; FRANK, J.E.; BUHR, R.J.; BAILEY, J.S. Hatching egg sanitization for prevention or reduction of human enteropathogens: a review. The Journal of Applied Poultry Research, v.9, p.279-284, 2000. DOI: 10.1093/ japr/9.2.279.

BRAUN, P.G.; FERNANDEZ, N.; FUHRMANN, H. Investigations on the effect of ozone as a disinfectant of egg surfaces. Ozone: science \& engineering: the journal of the international Ozone Association, v.33, p.374-378, 2011. DOI: 10.1080/01919512.2011.589359.

CADIRCI, S. Disinfection of hatching eggs by formaldehyde fumigation - a review. Archiv für Geflügelkunde, v.73, p.116123, 2009.

CHAVEZ, C.; KNAPE, K.D.; COUFAL, C.D.; CAREY, J.B. Reduction of eggshell aerobic plate counts by ultraviolet irradiation. Poultry Science, v.81, p.1132-1135, 2002. DOI: 10.1093/ps/81.8.1132.

CORRY, J.E.L.; JARVIS, B.; PASSMORE, S.; HEDGES, A. A critical review of measurement uncertainty in the enumeration of food micro-organisms. Food Microbiology, v.24, p.230-253, 2007. DOI: $10.1016 /$ j.fm.2006.05.003.

CORTÉS, C.R.; ISAÍAS, G.T.; CUELLO, C.L.; FLORES, J.M.V.; ANDERSON, R.C.; CAMPOS, C.E. Bacterial isolation rate from fertile eggs, hatching eggs, and neonatal broilers with yolk sac infection. Revista Latinoamericana de Microbiología, v.46, p.12-16, 2004.

COUFAL, C.D.; CHAVEZ, C.; KNAPE, K.D.; CAREY, J.B. Evaluation of a method of ultraviolet light sanitation of broiler hatching eggs. Poultry Science, v.82, p.754-759, 2003. DOI: 10.1093/ps/82.5.754.

COX, N.A.; RICHARDSON, L.J.; BUHR, R.J.; MUSGROVE, M.T.; BERRANG, M.E.; BRIGHT, W. Bactericidal effect of several chemicals on hatching eggs inoculated with Salmonella serovar Typhimurium. The Journal of Applied Poultry Research, v.16, p.623-627, 2007. DOI: 10.3382/japr.2007-00039.

FASENKO, G.M.; O'DEA CHRISTOPHER, E.E.; MCMULLEN, L.M. Spraying hatching eggs with electrolyzed oxidizing water reduces eggshell microbial load without compromising broiler production parameters. Poultry Science, v.88, p.1121-1127, 2009. DOI: $10.3382 /$ ps.2008-00359.

GOTTSELIG, S.M.; DUNN-HORROCKS, S.L.; WOODRING, K.S.; COUFAL, C.D.; DUONG, T. Advanced oxidation process sanitization of eggshell surfaces. Poultry Science, v.95, p.13561362, 2016. DOI: $10.3382 / \mathrm{ps} / \mathrm{pev} 450$.

GUALHANONE, A.; FURLAN, R.L.; FERNANDEZALARCON, M.F.; MACARI, M. Effect of breeder age on eggshell thickness, surface temperature, hatchability and chick weigh.
Brazilian Journal of Poultry Science, v.14, p.9-14, 2012. DOI: 10.1590/S1516-635X2012000100002.

MUSGROVE, M.T.; STEPHENS, C.B.; BOURASSA, D.V.; COX, N.A.; MAULDIN, J.M.; BERRANG, M.E.; BUHR, R.J. Enterobacteriaceae and Salmonella recovered from non sanitized and sanitized broiler hatching eggs. The Journal of Applied Poultry Research, v.23, p.516-522, 2014. DOI: 10.3382/japr.201400975.

ROBERT, J.R. Factors affecting egg internal quality and egg shell quality in laying hens. Journal of Poultry Science, v.41, p.161177, 2004. DOI: 10.2141 /jpsa.41.161.

ROQUE, L.; SOARES, M.C. Effects of eggshell quality and broiler breeder age on hatchability. Poultry Science, v.73, p.18381845, 1994. DOI: 10.3382/ps.0731838.

SANDER, J.E.; WILSON, J.L. Effect of hydrogen peroxide disinfection during incubation of chicken eggs on microbial levels and productivity. Avian Diseases, v.43, p.227-233, 1999. DOI: $10.2307 / 1592612$.

SHELDON, B.W; BRAKE, J. Hydrogen peroxide as an alternative hatching egg disinfectant. Poultry Science, v.70, p.1092-1098, 1991. DOI: 10.3382/ps.0701092.

SPICKLER, J.L.; BUHR, R.J.; COX, N.A.; BOURASSA, D.V.; RIGSBY, L.L. Comparison between rinse and crush-and-rub sampling for aerobic bacteria recovery from broiler hatching eggs after sanitization. Poultry Science, v.90, p.1609-1615, 2011. DOI: 10.3382/ps.2010-01305.

STEFANELLO, C.; SANTOS, T.C.; MURAKAMI, A.E; MARTINS, E.N.; CARNEIRO, T.C. Productive performance, eggshell quality, and eggshell ultrastructure of laying hens fed diets supplemented with organic trace minerals. Poultry Science, v.93, p.104-113, 2014. DOI: 10.3382/ps.2013-03190.

WELLS, J.B.; COUFAL, C.D.; PARKER, H.M.; KIESS, A.S.; PURSWELL, J.L.; YOUNG, K.M.; MCDANIEL, C.D. Hatchability of broiler breeder eggs following eggshell sanitization by repeated treatment with a combination of ultraviolet light and hydrogen peroxide. International Journal of Poultry Science, v.10, p.421-425, 2011. DOI: 10.3923/ijps.2011.421.425.

WELLS, J.B.; COUFAL, C.D.; PARKER, H.M.; MCDANIEL, C.D. Disinfection of eggshells using ultraviolet light and hydrogen peroxide independently and in combination. Poultry Science, v.89, p 2499-2505, 2010. DOI: 10.3382/ps.2009-00604.

WHISTLER, P.E.; SHELDON, B.W. Bactericidal activity, eggshell conductance, and hatchability effects of ozone versus formaldehyde disinfection. Poultry Science, v.68, p.1074-1077, 1989. DOI: $10.3382 /$ ps.0681074.

YAN, Y.-Y.; SUN, C.-J.; LIAN, L.; ZHENG, J.-X.; XU, G.-Y.; YANG, N. Effect of uniformity of eggshell thickness on eggshell quality in chickens. The Journal of Poultry Science, v.51, p.338342, 2014. DOI: 10.2141/jpsa.0130032.

ZEWEIL, H.S.; RIZK, R.E.; BEKHET, G.M; AHMED, M.R. Comparing the effectiveness of egg disinfectants against bacteria and mitotic indices of developing chick embryos. The Journal of Basic \& Applied Zoology, v.70, p.1-15, 2015. DOI: 10.1016/j. jobaz.2014.12.005.

Received on June 21, 2016 and accepted on December 19, 2017

Pesq. agropec. bras., Brasília, v.53, n.10, p.1177-1183, Oct. 2018 DOI: $10.1590 / \mathrm{S} 0100-204 \mathrm{X} 2018001000011$ 